\title{
Importance of Education and Nutrition Intervention on Drug Addiction Recovery
}

\author{
Soheir Fouad Nour ${ }^{1}$, Ekram R Soliman ${ }^{1}$, Samirah A Al-Humaidi ${ }^{1}$, and Mamdouh A Abou-Rayan ${ }^{2}$
}

\begin{abstract}
Addiction causes dietary and health problems that lead to malnutrition and psychological diseases. Therefore this research was carried out to study the impact of educational and nutritional intervention programs that focused on antioxidants and essential fatty acids especially omega 3. These programs aimed to improve the nutritional knowledge and modify attitudes, eating behavior, as well as to improve the nutritional status of the addicted patients.
\end{abstract}

The sample comprised 40 addicted males who were treated for rehabilitation at Maamoura Hospital of Psychiatric in Alexandria, Egypt. The required research data were collected using an especial questionnaire by interview, and they were treated statistically.

The duration of the educational program was 10 hours, among 5 days, and it was applied on all of the addicted sample, and individually for about an addition two hours, while the nutritional intervention program was applied for 30 days on 24 patients. Evaluation of the programs was done before, during and after application.

The results revealed that most of the patients were young, their ages were less than 30 years, and one third of them were suffering from health problems related to the liver, digestive as well as nervous systems. Before applying the nutritional education program, the percentage of patients who had right knowledge, positive attitudes and healthy practices were $25 \%, 47.5 \%$, and $55 \%$, respectively. These percentages increased after applying the program to be $100 \%, 60 \%$, and $100 \%$, respectively. The nutrition intervention program improved most of the nutritional studied parameters namely BMI, liver enzymes, and kidney functions, as well as decreased the percentage of patients who suffering from depression and improved their functional health.

So it was concluded that nutrition education and nutrition intervention programs are very important for treating addicted persons parallel with the medical and psychological treatments. These programs must be applied from the beginning phases of addiction treatment namely drug withdrawal and detoxification to help the liver and the other body organs to do their work efficiently.

\section{INTRODUCTION}

Drug addiction is one of the serious problems that worry the Egyptian government, as it deals with young people within the age of work and productivity (UNAIDS, 2004).
According to a 2007 study, addicts in Egypt are spending 2.9 billion US Dollars on drug each year. Estimates on how many people are addicted vary greatly, but range between 600,000 and 800,000 , the majority of them are between 15 and 25 years of age( El-Sawy et al, 2010).

In Egypt about half of 130,000 people who entered drug rehabs in 2007 were addicted to cannabis, while 43 $\%$ were dependent on opiates of various types, and 7\% were addicts of amphetamine-type stimulants ( El-Sawy et al, 2010).

In 2009, 4.5 million people worldwide were receiving treatment for problems related to using illicit drugs ( European Monitoring Centre for Drug and Drug Addiction, 2011).

According to a WHO report (2012), about 230 million people, or $5 \%$ of the world adult population, are estimated to have used an illicit drug at least once in 2010. Heroin, cocaine and other drugs kill around 0.2 Million people each year. Also, the report indicated that illicit drugs underline economic and social development , crime, inability, insecurity and may be spread of HIV (WHO, 2012).

The primary goals of drug-abuse treatment are abstinence, relapse prevention, and rehabilitation. Therefore drug-abuse treatment follows three main phases namely withdrawer, detoxification, and rehabilitation.

Geramian, et al.( 2012) defined drug abuse as a result of interaction between the individual, substance, and environment, in addition to knowledge and attitude of individuals regarding drugs and their effects on health status.

Many studies on drug addiction have demonstrated nutritional deficiencies, including weight loss and changes in dietary patterns (Alves, et al., 2011).

Ross et al. (2012) added that the forbidden drug use is a well-known risk factor for food insecurity and improper nutritional status. Drug addiction changes food consumption patterns, as eating fewer meals or often omission of some meals for an entire day and to depend on food availability.

\footnotetext{
${ }^{1}$ Department of Home Economics, Faculty of Agriculture, Alexandria University.

${ }^{2}$ Maamoura Hospital of Psychiatric, Alexandria, Egypt.

Received November 15, 2018, Accepted December 9, 2018
} 
Karajibani et al., (2014) stated that many factors affect the nutritional status of addicted including; lack of knowledge about negative effects of substances on bioavailability of nutrients, incorrect attitudes toward modification of food pattern, careless to food intake, low levels of self-confidence and lack of motivation and physical activity. Saeland (2014) found in her study entitled "eating on the edge" that most addicts exposed to poor dietary intake. She also mentioned that drug addiction is a disease due to the physical changes that occur in areas of the brain such as critical to judgment, decision making, behavior control, learning and memory.

Nutritional deficiencies can be a major cause of withdrawal-like symptoms such as fatigue, depression, irritability, and other conditions that block recovery and lead to relapse (Miller, 2012).

Many nutritionally-based programs find vitamin $\mathrm{C}$ to be one of the most essential ingredients in the treatment of addiction because it is a primary detoxifier of drugs and poisons from the body (Sathyanarayana et al., 2008). Vitamin C also helps counterbalance some of the withdrawal difficulties and can help rebuild the liver, adrenals, and immune system. It also helps the brain chemicals work properly by supporting the conversion of the amino acid tryptophan into serotonin.

Battaglia (2008) concluded that good nutrition, relaxation, and exercise all play an important role in successful detoxification from alcohol and drugs abuse. Learning to make healthy food choices is important to achieve a healthy lifestyle. Because they have neglected their diet for long time, addicts experience gastrointestinal disorders such as diarrhea, constipation and an inability to digest foods properly, parallel with a poor appetite. As a result, they have a special need for foods that are high in nutrients to rebuild damaged tissues and organs and to regain appropriate functioning of the various systems including the nervous and gastrointestinal systems.

Grotzkyj-Giorgi (2009) stated that whatever the addiction, nutrition should be considered a powerful ally in the process of recovery, particularly during the initial stages of detoxification. A varied diet rich in good carbohydrates, good quality proteins (lean meat, fish and vegetable proteins), fresh fruit and vegetables, essential fats (oily fish, nuts) and plenty of water should be considered and utilized as a tool to help the recovery process.

Carson (2012) confirmed that alcohol and drug addicts have deficiencies of omega- 3and omega 6 fatty acids, and that adding them to their program greatly aided recovery.
Malnutrition associated with drug abuse can be either primary or secondary.Primary malnutrition occurs when substance abuse displaces, reduces, or compromises food intake. Secondary malnutrition occurs when the substance of abuse causes alterations in the absorption, metabolism, utilization, and excretion of nutrients due to compromised oral, gastrointestinal, circulatory, metabolic, and neurological health (Wiss, 2013).

The aim of this study is to evaluate the necessity of the inclusion of unique nutrition education and intervention into substance abuse treatment programs, as well as to measure the impact of these programs on knowledge, attitudes, and behaviors towards nutrition and health.

\section{SUBJECTS AND METHODS}

Subjects: The present study is a descriptive and analytical study which included 40 addicted males. They represented all patients who were treated for rehabilitation at Maamoura Hospital of Psychiatric in Alexandria, Egypt. They spent about three months in the Hospital for withdrawal and detoxification treatments, and this study was done during their rehabilitation and recovery treatment(March to December, 2014).

Methods: The data were collected using a questionnaire by interview. The questionnaire comprised four sections. The purpose of the first section was to gather demographic information. The second section included anthropometric data (height, weight, BMI). The third section contained questions regarding appetite and health problems. The fourth section contained 3 tests to evaluate respectively the levels of knowledge, attitudes, and practices about foods and nutrition. Each test was applied using 3-item multiple choices. For each correct answer, 2 point, for false answer, zero, and for don't know or don't care, 1 point were considered.

Nutritional knowledge were evaluated using 30 statements. The answer choices were yes, no, and don't know. The mean score was calculated for each patient as three levels of low (0 -20), fair (21 -30), and high (31 $60)$.

Nutritional attitudes were assessed using 25 statements. The answer choices were agree, disagree, and don't care. The attitudes were evaluated as negative attitudes $(0-16)$, attitudes needed modification (17 $33)$, and positive attitudes $(34-50)$.

The nutritional practices assay included 9 statements. The answer choices were usually, sometimes, and seldom or never. The practice were evaluated as unhealthy nutritional practices $(0-6)$, faire needed to modify $(7-12)$, and healthy practices $(13-18)$. 
Nutrition Education Program: The nutrition education program was designed and performed by the researchers as face to face with the patients as groups and as well as individually. The program was implemented for 5 days, 2 hours a day, and individually for about an addition two hours. Educational tools were lecture supplemented with power point, booklet, pamphlet and poster.

The nutrition education program composed the following topics: food groups, food guide pyramid, principles of meal planning, antioxidant and its role in the detoxification process, and its food sources, good and bad fats, and the role of essential fatty acids in mood and healthy brain and body.

To evaluate the impact of the program on knowledge, attitude, and practice levels of the subjects, pre- and post-test were performed before and after the program.

Nutrition Intervention Program: Before implementing this program, the nutritional composition of the Hospital meals were analyzed using the Egyptian Food Composition Tables (National Institute for Nutrition, 2006). It is found that the quantity of the macronutrient were sufficient, but the meals were insufficient for addict persons in antioxidants and the essential omega-3 fatty acids which play very important role in the detoxification process in the liver, and in improving the mood and overall health status of the body (Table 5).

Therefore the following foods were suggested as good sources of antioxidants as well as the omega-3 fatty acids to add to the daily hospital meals and consumed as snacks: carrots, broccoli, beets, green pepper, guava, kiwi, pomegranate, flaxseed, yogurt, wheat germ, and green tea. Because of the patients didn't accept the taste of the broccoli, beets, and flaxseed, these foods were omitted and peanut was add instead as indicated in ( Table 1).

Table 1. Food of nutrition intervention program

\begin{tabular}{lc}
\hline Food & Amount $(\mathbf{g})$ / day \\
\hline Carrots & 150 \\
Guava & 180 \\
Kiwi & 85 \\
Pomegranate & 290 \\
Yogurt & 120 \\
Peanut & 100 \\
Wheat germ & 5,5 \\
Green tea (dry leaves) & 2 \\
\hline
\end{tabular}

All vegetables and fruits were consumed fresh. The wheat germ was added to the yogurt, and the green tea was used to make one drinking cup.
These foods provided approximately $530 \mathrm{mg}$ vitamin C, $4125 \mathrm{mcg}$ retinol activity equivalent (Vitamin A), 45 mg ATE (vitamin E), and $325 \mathrm{mg}$ omega-3-fatty acids (Table 6).

The duration of the nutritional intervention program was 30 days, and it was applied on only 24 patients, who continued their rehabilitation treatment in the hospital. The patients were divided in two groups, 12 for each. Group (A) were given the regular hospital meals plus the foods rich in antioxidants and omega 3 fatty acids for 15 days, and then nutritional supplements were given instead of the added food for another 15 days. Group (B) were given in addition to the regular hospital meals the supplements for 15 days and then the rich foods for another 15 days. Evaluation of the program was done before, during and after its application.

The supplements provided almost the same amounts of vitamins C, A, E, but more omega-3- fatty acids (2000 mg).

Anthropometric Measurements: Height and weight were measured using a stadio-meter and digital scale. Body mass index (BMI) was calculated for each patient before, during, and after implementing the nutritional intervention program.

Blood Analysis: Blood analysis were done in the hospital lab. The analysis included : liver enzymes (ALT, AST), the serum urea, and the ceratinine.

Functional Health Test: Functional health test (Holford, 1998) provides investigation to understand the body functions. It examines: leaky gut syndrome, digestive issues, hormonal imbalance, thyroid imbalance, anemia, stress and depression, and chronic fatigue syndrome.

The scoring instructions are as follows : less than 10 points (excellent health status), (from 10-19 points) good health status but needed more balanced meals, (from $20-29$ points) moderate health status and needed more balanced diets and improve the lifestyle, (from 30 -40) poor health status that needed health and balanced diets as well as supplements.

Hamilton Rating Scale for Depression: Hamilton developed a rating scale for determination the depression levels of individuals suffering from different causes of depression (Hamilton, 1967).

Hedlund and Viewing, (1979) stated that Hamilton item questionnaire is used to provide an indication of depression, and as a guide to evaluate recovery from drug addiction.

The scoring instructions of Hamilton test for depression are as follows: $0-7=$ normal, $8-13=$ mild depression, $14-18=$ moderate depression, $19-22=$ severe depression, and $\geq 23=$ very severe depression. 
Statistical Analysis: After the questionnaires were filled and collected, data was coded and entered the SPSS software, version 16, and analyzed. The mean and standard deviation was used for presentation of quantitative data. The (f) and (LSD) tests were used for comparison between means.P $<0.05$ was considered as the level of significant.

\section{RESULTS AND DISCUSSIONS}

Subjects' characteristics: The results in Table (2) shows that more than half of the studied addicts $(52.5 \%)$ aged less than 30 years.Concerning the educational level, the highest percentage of addicts in this study was that of preparatory and secondary school education (45\%), while illiteracy was observed among (10\%), and another $(10 \%)$ for whom can read and write only.

Table 2. Subjects' socio-economic characteristics $(\mathrm{n}=\mathbf{4 0})$

\begin{tabular}{lcc}
\hline Character & Number & \% \\
\hline Age (years) & & \\
15 -Less than 30 & 21 & 52.5 \\
30 - less than 40 & 12 & 30.0 \\
40 and more & 7 & 17.5 \\
Educational Status & & \\
Illiterate & 4 & 10.0 \\
Read and write only & 4 & 10.0 \\
Preparatory level & 14 & 35.0 \\
Secondary level & 9 & 22.5 \\
High education & 9 & 22.5 \\
Occupation & & \\
Manual worker & 30 & 75.0 \\
Small business & 4 & 10.0 \\
Unemployed / students & 6 & 15.0 \\
Marital Status & & \\
Married & 16 & 40.0 \\
Single & 16 & 40.0 \\
Divorced & 8 & 20.0 \\
Monthly Income & & \\
Less than 2000 EGP & 30 & 75.0 \\
2000 - < 4000 EGP & 7 & 17.5 \\
4000 EGP and more & 3 & 7.5 \\
\hline
\end{tabular}

Manual workers represented the majority of sample size $(88.2 \%)$, while the percentage of the unemployed was $(5 \%)$, and the patients who were still studying represented $(10 \%)$ of the sample.Addicts who married were found to be $(40 \%)$, and a same percentage $(40 \%)$ were single, while the rest $(20 \%)$ were divorced.

The monthly income of $(75 \%)$ of the studied patients was less than 2000 EGP, while it was more than 4000 EP for only $(7.5 \%)$. These indicated that most of the sample may suffered from financial problems.
The data in Table (3) shows that the majority of studied addicts (90\%) were abusing more than one drug, and the percentage of who were abusing three drugs represented $(62.5 \%)$.

Heroin was abused among (77.5\%), then hashish (65\%), followed by morphine (45\%), and then alcohol (30\%) (Table 3). In addition, the data indicated that the majority of patients $(95 \%)$ were current smokers.

Table 3. Number of drug abused, times per day and type of drug $(n=40)$

\begin{tabular}{lcc}
\hline Terms & Number & \% \\
\hline Number of drug abused & & \\
1 & 4 & 10.0 \\
2 & 11 & 27.5 \\
$>2$ & 25 & 62.5 \\
Times per day & & \\
2 & 8 & 20 \\
3 & 8 & 20 \\
$>3$ & 24 & 40 \\
Type of drug & & \\
Heroine & 31 & 77.5 \\
Hashish & 26 & 65 \\
Morphine & 18 & 45 \\
Stimulants & 16 & 40 \\
Amphetamine & 15 & 37.5 \\
Alcohol & 12 & 30 \\
\hline
\end{tabular}

The most motives for drug abuse were found to be peer pressure (75\%), family troubles (25\%), and seeking pleasure $(17.5 \%)$. These results are in agreement with different studies such as those done in Bangladesh (Haque et al. 2014). The National Drug Intelligence Center (2011) suggested that factors such as peer pressure, physical, stress, and quality of parenting can greatly influence the occurrence of drug abuse and the escalation to addiction in a person's life.

Concerning multiple health problems that the subjects suffered from as they reported were liver $(37.5 \%)$, digestive system $(35 \%)$, nervous system $(32.5 \%)$, and kidney $(10 \%)$.

Because of addiction relapse, most of the patients $(85 \%)$ were treated more than one time. The frequency of motives for seeking recovery treatment were found to be dissatisfaction with being addicts $(77.5 \%)$, and health troubles $(55 \%)$.

Impact of nutrition education program on knowledge, attitudes and practices

The data in Table (4) shows a significant improvement in all of the studied nutritional parameters $(\mathrm{P} \leq 0.05)$ namely knowledge, attitudes and practices. Before implementing the program the nutritional 
knowledge level of $(75 \%)$ of the patients was low, and only $(5 \%)$ of them answered most of the nutritional test correctly. After implementing the program the nutritional knowledge level of all the patients improved to be high. The same trend was observed for the patents' eating practices. Only (55\%) of the patients followed a healthy eating practices before the program increased to be $(100 \%)$ after the program. On the other hand, because the difficulty of changing the attitudes in comparison with knowledge and practices, only (60\%) of the patients had positive attitudes towered some foodsafter the program, while this percentage was $(47.5 \%)$ before the program. These results indicated that the nutritional education program succeeded to inform the subjects about the importance of introduce healthy foods rich in antioxidants, and other micronutrients as well as the good fats which high in essential fatty acids especially the omega-3 fatty acids.

A study by Barbadora et al. (2011) investigated the impact of education programs on nutritional knowledge and behaviors of 58 alcohol dependent participants in an inpatient treatment facility in Italy. They found a positive effect of the nutrition education on the participants'knowledge among nutrition, food, and health rather than their behaviors.

Cowan and Devine (2013) mentioned that education process must be began early in recovering to emphasize the importance of choosing nutritious foods, as well as to understand the role that food plays in recovery from drug addiction.

This study shows that nutritional knowledge, attitude and practice were higher after performance of nutritional educational program for addict patients $(\mathrm{P}<0.05)$. This finding indicates that drug addicts were successful in receiving nutritional information through this nutritional program. In similar study, Richardson and Wiest (2015) stated that given impact of nutrition on health for addicted is important aspect of drug treatment. Grant $e t$ al. (2004) found that nutrition education programs provided to the substance abuse population have been significantly improved three-month sobriety success rates.Therefore, patients must be educated about the importance of nutrition in their recovery process. They must be encouraged to understand how nutrition can play an important part in their recovery process, and they need help navigating the struggles that arise so they can achieve a healthful lifestyle

\section{The Nutrition Intervention Program}

Table (5) shows the nutrient contents of the Hospital meals for four days, which repeated each week, as well as the mean quantities provided per person per day.The mean of the hospital daily meal provided, $2729 \mathrm{Kcal}$, $100 \mathrm{~g}$ protein, $90 \mathrm{~g}$ fat, $395 \mathrm{~g}$ carbohydrates, $101 \mathrm{mg}$ vitamin C, and $686 \mathrm{mcg}$ vitamin A (Retinol Activity Equivalent), $17 \mathrm{mg}$ vitamin $\mathrm{E}$ (Alpha-Tocopherol Equivalent), and $490 \mathrm{mg}$ omega-3 fatty acids. The means of vitamins and omega-3 fatty acids content of the hospital daily meal were suitable for healthy people, but not adequate for recovering from drug addiction (Hass, 2006, and Carson, 2012). Vitamin C, A, and E are powerful antioxidants that protect tissues and organs in the body from free radicals that are produced by toxins. The recommended dose of vitamin $\mathrm{C}$ for substance abuse detoxification is 2 to 3 grams per day, taken from supplements in divided doses (Hass, 2006, and Carson, 2012). Results from pharmacokinetic studies indicate that $200-300 \mathrm{mg} /$ day intake provided from consuming vitamin $\mathrm{C}$ rich foods are about four times higher than oral doses of the same amounts (Padayatty et al., 2004). This is because the vitamin $\mathrm{C}$ in food is more bioavailable than the supplements, therefore $600-700 \mathrm{mg}$ of vitamin $\mathrm{C}$ per day are adequate for drug addicts.

Table 4. Impact of the education program on level of nutritional knowledge, attitudes, and practices

\begin{tabular}{lcccc}
\hline \multirow{2}{*}{ Levels } & \multicolumn{2}{c}{ Before Program } & \multicolumn{2}{c}{ After program } \\
\cline { 2 - 4 } & Number & \% & Number & 0 \\
\hline Knowledge & 30 & 75 & 0 & 0 \\
Low & 8 & 20 & 0 & 100 \\
Moderate & 2 & 5 & 40 & 0 \\
High & & & & 40 \\
Attitudes & 0 & 0 & 0 & 60 \\
Negative & 21 & 52.5 & 16 & 0 \\
Needed modification & 19 & 47.5 & 24 & 0 \\
Positive & & & & 100 \\
Practice & 0 & 0 & 0 & 0 \\
Unhealthy & 18 & 45 & 0 & \\
Needed modification & 22 & 55 & 40 & \\
healthy & & & & \\
\hline
\end{tabular}


Table 5. Calories and nutrients contents of the Hospital meals

\begin{tabular}{lcccccccc}
\hline Nutrient & $\begin{array}{c}\text { Calories } \\
\text { Kcal }\end{array}$ & $\begin{array}{c}\text { Protein } \\
\mathbf{g}\end{array}$ & $\begin{array}{c}\text { Fat } \\
\mathbf{g}\end{array}$ & $\begin{array}{c}\text { Carbohydrate } \\
\mathbf{g}\end{array}$ & $\begin{array}{c}\text { Vit. C } \\
\mathbf{M g}\end{array}$ & $\begin{array}{c}\text { Vit. A } \\
\text { RAE } \\
\text { mcg }\end{array}$ & $\begin{array}{c}\text { Vit. E } \\
\text { ATE } \\
\text { mg }\end{array}$ & $\begin{array}{c}\text { n-3 FA } \\
\text { mg }\end{array}$ \\
\hline $1^{\text {st }}$ day & 3180 & 100 & 89 & 495 & 123 & 748 & 15 & 514 \\
$2^{\text {ed }}$ day & 2622 & 110 & 96 & 330 & 80 & 618 & 23 & 481 \\
$3^{\text {ed }}$ day & 3140 & 112 & 88 & 475 & 121 & 758 & 16 & 518 \\
$4^{\text {th }}$ day & 2224 & 78 & 87 & 282 & 80 & 618 & 13 & 446 \\
Mean/day & 2792 & 100 & 90 & 395 & 101 & 686 & 17 & 490 \\
\hline
\end{tabular}

RAE $=$ Retinol Activity Equivalent, ATE $=$ Alpha-Tocopherol Equivalent

Like vitamin $\mathrm{C}$, vitamin $\mathrm{E}$ is an antioxidant that protects the cells from damage by inhibiting the development of free radicals. The recommended daily dose for addicts is $100 \mathrm{IU}$ or $67 \mathrm{mg}$ ATE (Carson, 2012).

Vitamin A (retinol + beta-carotene) has antioxidant properties, and its recommended daily intake for addicts is ranged from 4000 to $5000 \mathrm{mcg}$ RAE (Hass, 2006). The daily requirements of omega- 3 fatty acids for men is $2 \mathrm{~g}$ (FAO, 2008). Therefore the hospital meals were deficient in the antioxidant vitamins as well as the essential omega-3 fatty acids which very crucial for enhancing the detoxification process.

Table (6) shows the calories and nutrients content of the provided foods used as snacks in the nutrition intervention program for 30 days.

Data in Table (7) shows the total calories and nutrients contents provided to the patients during the nutritional intervention program.

As indicated from the data in Table (7) all of the amounts of the studied vitamins increased about 6 times and the amount of the omega-3 fatty acids increased about two times after implementing the nutritional intervention program, and these amounts are more suitable for requirements of the patients.

\section{Impact of the Nutrition Intervention Program on Nutritional Status}

The body mass index was used as an indicator for the nutritional status of the patients. As indicated from the data in Table (8) one third of the total sample suffered from under weight before implementing the program decreased to one fourth and then to one eights after 15 days and 30 days, respectively. The percentage of the patients who had normal weight was $33.3 \%$ before the program, increased to $50 \%$ after 15 days and then to $66.7 \%$ at the end of the program, while the patients who suffered from overweight represented one third decreased to one fifth after 30 days of implementing the intervention program.

In general the nutritional status of the two studied groups were improved significantly $(P \geq 0.5)$.

Table 6. Calories and nutrients contents of added foods suggested to the intervention program

\begin{tabular}{lcccccccc}
\hline Food & $\begin{array}{c}\text { Calories } \\
\text { Kcal }\end{array}$ & $\begin{array}{c}\text { Protein } \\
\text { g }\end{array}$ & $\begin{array}{c}\text { Fat } \\
\text { g }\end{array}$ & $\begin{array}{c}\text { Carbo- } \\
\text { hydrate } \\
\text { G }\end{array}$ & $\begin{array}{c}\text { Vit. C } \\
\text { mg }\end{array}$ & $\begin{array}{c}\text { Vit. A } \\
\text { RAE } \\
\text { mcg }\end{array}$ & $\begin{array}{c}\text { Vit. E } \\
\text { ATE } \\
\text { Mg }\end{array}$ & $\begin{array}{c}\text { n-3 FA } \\
\text { mg }\end{array}$ \\
\hline Carrots & 66.8 & 1.4 & 0.4 & 14.4 & 10.0 & 3698.0 & 1.0 & 3.1 \\
Guava & 122.1 & 4.6 & 1.7 & 22.1 & 410.0 & 335.0 & 1.3 & 202.0 \\
Kiwi & 47.2 & 0.9 & 0.4 & 10.0 & 78.1 & 22.0 & 1.3 & 36.0 \\
Pomegranate & 229.4 & 4.2 & 1.4 & 50.0 & 30.0 & 10.0 & 1.8 & - \\
Yogurt & 47.8 & 5.6 & 0.5 & 5.2 & 1.1 & 60.0 & 8.4 & 32.4 \\
Peanut & 566.2 & 25.0 & 45.0 & 15.3 & 0.8 & - & 11.2 & 10.0 \\
Wheat germ & 22.6 & 1.3 & 0.6 & 3.0 & - & - & 20.0 & 42.0 \\
Green tea+ sugar & 16.0 & - & - & 4.0 & - & - & - & - \\
Total & 1118.1 & 44.3 & 50.0 & 128.0 & 530.0 & 4125.0 & 45.0 & 325.5 \\
\hline
\end{tabular}

Table 7. Calories and nutrients contents provided to the patients during the nutritional intervention program

\begin{tabular}{lcccccccc}
\hline Meal & $\begin{array}{c}\text { Calories } \\
\text { Kcal }\end{array}$ & $\begin{array}{c}\text { Protein } \\
\mathbf{g}\end{array}$ & $\begin{array}{c}\text { Fat } \\
\mathbf{g}\end{array}$ & $\begin{array}{c}\text { Carbohydrate } \\
\mathbf{g}\end{array}$ & $\begin{array}{c}\text { Vit. C } \\
\mathbf{M g}\end{array}$ & $\begin{array}{c}\text { Vit. A } \\
\text { RAE } \\
\mathbf{m c g}\end{array}$ & $\begin{array}{c}\text { Vit. E } \\
\text { TAE } \\
\text { mg }\end{array}$ & $\begin{array}{c}\mathbf{n - 3} \text { FA } \\
\text { mg }\end{array}$ \\
\hline Hospital & 2792 & 100 & 90 & 395 & 101 & 686 & 17 & 490 \\
Program & 1118 & 44 & 50 & 128 & 530 & 4125 & 45 & 325 \\
Total & 3910 & 144 & 140 & 523 & 631 & 4811 & 62 & 815 \\
\hline
\end{tabular}


Table 8. Percentage distribution of patients according to nutritional status (BMI)

\begin{tabular}{lccccccccc}
\hline & \multicolumn{3}{c}{$\begin{array}{c}\text { Group A } \\
\mathbf{n = 1 2}\end{array}$} & \multicolumn{3}{c}{$\begin{array}{c}\text { Group B } \\
\mathbf{n = 1 2}\end{array}$} & \multicolumn{3}{c}{ Total } \\
$\mathbf{n = 2 4}$
\end{tabular}

Impact of the Nutrition Intervention Program on Heath Status

\section{Liver Function}

Table (9) shows the mean and standard deviation of the serum liver enzymes (ALT) and (AST). The results show significant improvements in the serum levels of these enzymes, indicating that some liver heath problems may occurred before applying the nutrition intervention program (especially group A), but consuming foods rich in antioxidants and essential fatty acids as well as supplements prevents the liver cells from damage caused by using the illicit drugs.

For the case of (group A), consuming the foods for 15 days caused $(37.9 \%)$ decrease in the ALT level, when followed by using the nutrient supplements for another 15 days, the decrease was (20.9\%). While when the patients in (group B) received first the nutrient supplements for 15 days followed by consuming the foods, the decreases in the ALT levels were (12.7\%) and $(30.4 \%)$, respectively. Almost the same trend was observed in the case of the liver enzyme AST.

The benefits of eating fruits and vegetables may be much greater as compared to the effects imparted by any of the individual antioxidants they contain because the various vitamins, minerals and phytochemicals in these whole foods may act synergistically (Brown et al., 1990, Zaidi and Banu 2004).

\section{Kidney Function}

Table (10) shows the mean and standard deviation of the serum content of urea and creatinine before and after implementing the intervention program. In general the studied patients had normal urea as well as creatinine levels. However the program improved significantly the level of serum urea in both groups (A and B).

\section{Depression Level}

Before applying the nutritional intervention program all the patients were suffering from very severe depression (Table 11). At the end of the program only $50 \%$ had some depression symptoms $(41.7 \%$ low, and $8.3 \%$ moderate). These results confirmed that fresh food consumption is more effective than the supplements.

Table (12) indicates that $(8.3 \%)$ of the total studied patients were evaluated as suffering from poor functional health. After implementing the nutrition intervention program $(91.7 \%)$ of them improved their functional health to be excellent $(41.7 \%)$, and good $(50 \% \%)$.

Table 9. Mean levels of serum liver enzymes

\begin{tabular}{|c|c|c|c|c|c|c|}
\hline \multicolumn{7}{|c|}{ 1- Alanine aminotransferase (ALT) } \\
\hline Group & $\begin{array}{c}\text { Normal } \\
\text { level }\end{array}$ & $\begin{array}{c}\text { Before } \\
\text { Program }\end{array}$ & $\begin{array}{c}\text { After } \\
15 \text { days }\end{array}$ & $\begin{array}{c}\text { After } \\
\text { 30 days }\end{array}$ & $\mathbf{F}$ & LSD \\
\hline $\mathrm{A}(\mathrm{n}=12)$ & $<42 \mathrm{U} / \mathrm{L}$ & $50.9 \pm 7.77^{\mathrm{a}}$ & $31.6 \pm 8.65^{b}$ & $25.0 \pm 9.75^{\mathrm{c}}$ & S & 7.314 \\
\hline$\%$ decrease & - & - & $(37.9 \%)$ & $(20.9 \%)$ & & \\
\hline$B(n=12)$ & $<42 \mathrm{U} / \mathrm{L}$ & $34.5 \pm 2.89^{\mathrm{a}}$ & $30.1 \pm 12.6^{\mathrm{a}}$ & $21.5 \pm 3.58^{\mathrm{b}}$ & S & 7.091 \\
\hline$\%$ decrease & - & - & $(12.7 \%)$ & $(30.4 \%)$ & & \\
\hline \multicolumn{7}{|c|}{ 2- Aspartate aminotransferase (AST) } \\
\hline Group & $\begin{array}{c}\text { Normal } \\
\text { level }\end{array}$ & $\begin{array}{c}\text { Before } \\
\text { Program } \\
\end{array}$ & $\begin{array}{c}\text { After } \\
15 \text { days }\end{array}$ & $\begin{array}{c}\text { After } \\
\text { 30 days }\end{array}$ & $\mathbf{F}$ & LSD \\
\hline $\mathrm{A}(\mathrm{n}=12)$ & $<37 \mathrm{U} / \mathrm{L}$ & $39.7 \pm 0.39^{\mathrm{a}}$ & $28.1 \pm 4.25^{\text {a }}$ & $22.1 \pm 1.13^{\mathrm{b}}$ & $\mathrm{S}$ & 8.675 \\
\hline$\%$ decrease & - & - & $(29.2 \%)$ & $(21.4 \%)$ & & \\
\hline $\begin{array}{l}B(n=12) \\
\% \text { decrease }\end{array}$ & $<37 \mathrm{U} / \mathrm{L}$ & $28.2 \pm 7.39^{\mathrm{a}}$ & $\begin{array}{r}26.3 \pm 2.56^{\mathrm{a}} \\
(6.7 \%)\end{array}$ & $\begin{array}{r}19.9 \pm 1.48^{\mathrm{b}} \\
(24.3 \%)\end{array}$ & $\mathrm{S}$ & 8.318 \\
\hline
\end{tabular}

$\mathrm{S}=$ significant at $\mathrm{P} \leq 0.05$ 
Table 10. Mean levels of serum urea and creatinine

\begin{tabular}{lcccccc}
\hline Urea & Normal level & $\begin{array}{c}\text { Before } \\
\text { Program }\end{array}$ & $\begin{array}{c}\text { After } \\
\mathbf{1 5} \text { days }\end{array}$ & $\begin{array}{c}\text { After } \\
\mathbf{3 0 ~ d a y s}\end{array}$ & F & LSD \\
\hline $\mathrm{A}(\mathrm{n}=12)$ & $15-45 \mathrm{mg} / \mathrm{dL}$ & $37.4 \pm 3.9^{\mathrm{a}}$ & $29.0 \pm 3.41^{\mathrm{b}}$ & $28.7 \pm 2.60^{\mathrm{b}}$ & $\mathrm{S}$ & 2.073 \\
$\%$ decrease & - & - & $(22.3 \%)$ & $(1.2 \%)$ & & \\
$\mathrm{B}(\mathrm{n}=12)$ & $15-45 \mathrm{mg} / \mathrm{dL}$ & $37.4 \pm 2.99^{\mathrm{a}}$ & $29.4 \pm 3.23^{\mathrm{b}}$ & $27.5 \pm 2.49^{\mathrm{b}}$ & $\mathrm{S}$ & 1.797 \\
$\%$ decrease & - & - & $(21.4 \%)$ & $(6.3 \%)$ & & \\
\hline Creatinine & Normal level & $\begin{array}{c}\text { Before } \\
\text { program }\end{array}$ & $\begin{array}{c}\text { After } \\
\mathbf{1 5} \text { days }\end{array}$ & $\begin{array}{c}\text { After } \\
\mathbf{3 0 ~ d a y s}\end{array}$ & $\mathbf{F}$ & LSD \\
\hline $\mathrm{A}(\mathrm{n}=12)$ & $0.6-1.4 \mathrm{mg} / \mathrm{dL}$ & $1.03 \pm 0.03^{\mathrm{a}}$ & $1.01 \pm 1.40^{\mathrm{a}}$ & $1.20 \pm 0.05^{\mathrm{a}}$ & $\mathrm{NS}$ & 0.3917 \\
$\mathrm{~B}(\mathrm{n}=12)$ & $0.6-1.4 \mathrm{mg} / \mathrm{dL}$ & $1.04 \pm 0.04^{\mathrm{a}}$ & $1.06 \pm 0.03^{\mathrm{a}}$ & $1.24 \pm 0.05^{\mathrm{a}}$ & $\mathrm{NS}$ & 0.2287 \\
\hline
\end{tabular}

Data sharing a subscript letter in a row are not significantly different $(P>0.05)$

Table 11. Percentage distribution of patients according to depression level

\begin{tabular}{lcccccc}
\hline Group & \multicolumn{2}{c}{$\begin{array}{c}\text { Group A } \\
\mathbf{n = 1 2}\end{array}$} & \multicolumn{2}{c}{$\begin{array}{c}\text { Group B } \\
\mathbf{n = 1 2}\end{array}$} & \multicolumn{2}{c}{$\begin{array}{c}\text { Total } \\
\mathbf{n = 2 4}\end{array}$} \\
\hline $\begin{array}{l}\text { Depression } \\
\text { level }\end{array}$ & $\begin{array}{c}\text { Before } \\
\text { program }\end{array}$ & $\begin{array}{c}\text { After } \\
\text { program }\end{array}$ & $\begin{array}{c}\text { Before } \\
\text { Program }\end{array}$ & $\begin{array}{c}\text { After } \\
\text { Program }\end{array}$ & $\begin{array}{c}\text { Before } \\
\text { Program }\end{array}$ & $\begin{array}{c}\text { After } \\
\text { Program }\end{array}$ \\
\hline None & 0.0 & 66.7 & 0.0 & 33.3 & 0.0 & 50.0 \\
Low & 0.0 & 33.3 & 0.0 & 50.0 & 0.0 & 41.7 \\
Moderate & 0.0 & 0.0 & 0.0 & 16.7 & 0.0 & 8.3 \\
Severe & 0.0 & 0.0 & 0.0 & 0.0 & 0.0 & 0.0 \\
Very severe & 100.0 & 0.0 & 100.0 & 0.0 & 100.0 & 0.0 \\
\hline
\end{tabular}

Table 12. Percentage distribution of patients according to functional health status

\begin{tabular}{|c|c|c|c|c|c|c|}
\hline \multirow{2}{*}{$\begin{array}{l}\text { Group } \\
\text { functional } \\
\text { healthstatus }\end{array}$} & \multicolumn{2}{|c|}{$\begin{array}{c}\text { Group A } \\
n=12\end{array}$} & \multicolumn{2}{|c|}{$\begin{array}{c}\text { Group B } \\
\mathbf{n}=\mathbf{1 2}\end{array}$} & \multicolumn{2}{|c|}{$\begin{array}{c}\text { Total } \\
\mathrm{n}=\mathbf{2 4}\end{array}$} \\
\hline & $\begin{array}{c}\text { Before } \\
\text { program }\end{array}$ & $\begin{array}{c}\text { After } \\
\text { program }\end{array}$ & $\begin{array}{c}\text { Before } \\
\text { Program }\end{array}$ & $\begin{array}{c}\text { After } \\
\text { Program }\end{array}$ & $\begin{array}{c}\text { Before } \\
\text { program }\end{array}$ & $\begin{array}{c}\text { After } \\
\text { Program }\end{array}$ \\
\hline Excellent & 0.0 & 33.3 & 0.0 & 50.0 & 0.0 & 41.7 \\
\hline Good & 33.3 & 50.0 & 33.3 & 50.0 & 33.3 & 50.0 \\
\hline Moderate & 50.0 & 16.7 & 66.7 & 0.0 & 58.3 & 8.3 \\
\hline Poor & 16.7 & 0.0 & 0.0 & 0.0 & 8.3 & 0.0 \\
\hline
\end{tabular}

\section{CONCLUSION}

The impact of nutrition education program was effective in improving the patient's knowledge and behavior in comparison with their attitudes. It is known that changing the attitudes required more time. Therefore, patients must be educated on the importance of nutrition in their recovery process. They must be encouraged to understand how nutrition can play an important part in their recovery process.

The nutrition intervention program provided food sources of the antioxidant vitamins (C, E, and betacarotene) and may be other phytochemicals found in the provided foods that boost brain functions, as well as boost the detoxification process in the liver, and prevent all the body organs from free radicals damages.

Because of illicit drugs deplete omega-3 fatty acids from the brain (Somer, 1999), the intervention program provided food sources of omega-3 fatty acids, that give brain cells their ability to readily transport nutrients into the cell and quickly remove waste products. Omega-3 fatty acids also help in regulating the hormone like components, which further influence brain function and the release of neurotransmitters which improve the mood and behavior.

\section{REFERENCES}

Alves D., A.F. Costa, D. Custódio, L. Natário, V. FerroLebres and F. Andrade. 2011. Housing and employment situation, body mass index and dietary habits of heroin addicts in methadone maintenance treatmentAssociation for the Application of Neuroscientific Knowledge to Social Aims. AU-CNS. 13(1):1592-638.

Battaglia, E. 2008.Nutritional therapies for addiction. DrugRehab. Retrieved April 22. 2009. from: http://www.drugrehab.com/ addiction-nutritional-therapy.htm

Barbadora, P., E. Ponzio, M.E.Pertosa, F. Alitta, M.M. D'Errico, E. Prospero and A. Minelli. 2011. The effect of educational intervention on nutritional behavior in alcohol-dependent patients. Alcohol and Alcoholism (Oxford, Oxford shine).46(1): 77-79. 
Brown, R.J., K. Blum and M.C. Trachtenberg.1990. Neurodynamics of relapse prevention: a neuronutrient approach to outpatient DUI offenders. Journal of PsychoactiveDrugs.22 (2): 173-187.

Carson R.E. 2012. The Brain Fix: What's the Matter With Your Gray Matter: Improve Your Memory, Moods, and Mind. Health Communications Publisher.

Cowan. J., Devine, C. 2008. Food, eating and weight concerns of men in recovery from substance addiction. Appetite.50 (1): 33-42.

Cowan, J. and C. Devine. 2013. Diet and body composition outcomes of an environmental and educational intervention among men in treatment for substance addiction. J NutrEducBehav. 45 (2):154-158

El-Sawy, H., M. Abdel Hay and A. Badawy. 2010. Gender Differences in Risks and Pattern of Drug Abuse in Egypt. Egypt J Neurol Psychiat Neurosurg. 2010. 47(3): 413-418.

European Monitoring Centre for Drugs and Drug Addiction, Annual Report. 2011.The State of the Drugs (1). .Problem in Europe (Luxembourg, Publications Office of the European Union.

FAO. 2008. Fats and fatty acids in human nutrition: Report of an expert consultation, 10-14 November, Geneva,Switzerland.

Hamilton, M. 1967. Development of a rating scale for primary depressive illness. British Journal of Social and Clinical Psychology 6: 278-96.

Haque, M.M., M.R. Bhuiyan, S. Chowdhury, K. Islam. 2014. Nutritional Status and Dietary Intake Pattern of Male Drug Addicts Undergoing Rehabilitation. J Nutr Health Food Eng 1(1).

Hass. 2006. Staying Healthy with Nutrition. $1^{\text {st }}$ Edition. Library of Congress Cataloging, in Publication Data, USA.

Hedlund, J.L., B.W. Vieweg. 1979. The Hamilton Rating Scale for Depression: A Comprehensive Review. J. Operational Psychiatry. 10:149-165.

Holfordm P. 1998. 100\% Health - The Drug Free Guide for Feeling Better, Living Longer, and Stay Free from Disease. $1^{\text {st }}$ Edition, Judy Piatkus Publ. ,LTD.

Holford, P., D. Miller and J. Braly. 2008. How to quit without feeling $\mathrm{s}^{* *} \mathrm{t}$. London: Piatkus Books.

Islam, S.K.N., K.J. Hossain and A. Ahmed. 2002. Nutritional status of drug addicts undergoing detoxification . Brit $\mathrm{J}$ Nut. 88. (5): 507-13.

Geramian, N., S. Akhavan, L. Gharaat, A.M. Tehrani and Z. Farajzadegan. 2012. Determinants of drug abuse in high school students and their related knowledge and attitude. J Pak Med Assoc. 62(3 Suppl 2):S62-6.

Grant, L.P., B. Haughton and D.S. Sachan. 2004.Nutrition education is positively associated with substance abuse treatment program outcomes. J Am Diet Assoc. 104(4):604-610.

Grotzkyj-Giorgi, M. 2009.Nutrition and addiction- can dietary changes assist with recovery. Drug and Alcohol Today 9 (2): 24-8.
Karajibani, M., F. Montazerifar, A. Dashipour, K. Lashkaripour, M. Abery and S. Salari. 2014.Effectiveness of Educational Programs on Nutritional Behavior in Addicts Referring to Baharan Hospital, Zahedan (Eastern of IR Iran).Int J High Risk Behav Addict. Jun. 3(2): e18932.

Kowalchuk, A. and B.C. Reed. 2016. Substance use disorders. In: Rakel RE, Rakel DP, eds. Textbook of Family Medicine. 9th ed. Philadelphia, PA: Elsevier Saunders; chap 50.

Miller, R.P. 2012. Nutrition in addiction recovery. Many Hands Sustainability Center,USA. C.F. http://manyhandssustainabilitycenter.org

National Drug Intelligence Center. 2011. The Economic Impact of Illicit Drug Use on American Society. Washington D.C.: United States Department of Justice. Available at: http://www.justice.gov/archive/ndic/pubs44/44731/447 31p.pdf(PDF, 2.4MB)

National Institute for Nutrition. 2006. Food Composition Tables for Egypt. 2ed Edition,Cairo, Egypt.

Richardson, R.A. and K. Wiest. 2015. A Preliminary Study Examining Nutritional Risk Factors, Body Mass Index, and Treatment Retention in Opioid-Dependent Patients. J Behav Health Serv Res. 42(3):401-8.

Ross, L.J., M. Wilson, M. Banks, F. Rezannah and M. Daglish. 2012. Prevalence of malnutrition and nutritional risk factors in patients undergoing alcohol and drug treatment. Nutrition. 28(7-8):738-43.

Padayatty, S.J., H. Sun, Y. Wang, H.D. Riordan, S.M. Hewitt, A. Katz, R.A. Wesley and M. Levine. 2004. Vitamin C pharmacokinetics: implications for oral and intravenous use. Ann Intern Med. 6.140 (7): 533-537.

Sæland, M.E. 2014.Eating on the Edge. A study focusing on dietary habits and nutritional status among illicit drug addicts in Oslo, Norway. Doctor Thesis. Department of Health, Nutrition and Management, Faculty of Health Sciences,Oslo and Akershus University College of Applied Sciences.

Sæland, M.E., M. Haugen, F.L. Eriksen, A. Smehaugen, M. Wandel, T. Bohmer and A.Oshaug. 2009. A study focusing on nutrition and health of drug addict in Oslo, Norway. Public Health Nutr. 12 (5): 630-6.

Sathyanarayana, Rao. T.S., M.R. Asha, B.N. Ramesh and Rao. K.S. Jagannatha. 2008. Understanding nutrition, depression, and mental illnesses. Indian J Psychiatry.50(2):77-82.

Somer, E. 1999. Food and Mood. The Complete Guide to Eating Well and Feeling Your Best. Second Edition. Henry Holt and Company. N.Y.

Steel, R.G.D., J.H. Torrie and D. Dickey. 1997. Principles and Procedures of Statistics. A biometrical approach. 3rd ed. McGraw Hills Book Co. Inc. New York.

UNAIDS. 2004. Joint United Nations Program on HIV/AIDS. UNAIDS at Country Level Progress Report. 
Wiss, D.A. 2013. Nutrition and substance abuse. M.S. Thesis, Dept Family and Consumer Sciences, California State University, Northridge, USA.Retrived from http://hdl.handle.net/10211.2/3444.
WHO. 2012. Global Health Risk: Mortality and Burden of Disease Attributable to Selected Major Risks. World Health Organization. 2010.

Zaidi, A. and N. Banu. 2004. Antioxidant potential of vitamins $\mathrm{A}, \mathrm{E}$ and $\mathrm{C}$ in modulating oxidative stress in rat brain. Clinica Chimica Acta 340 :229-233.

\section{الملخص العربي}

\section{أهمية التخل التثقيفي والغذائي لعلاج إدمان المخدرات}

سهير فؤاد نور ، إكرام رجب سليمان، سميرة عالي الحامدي، ممدوح أبو ريان

صحية مرتبطة بالكبد والجهاز الهضمي والجهاز العصبي. قبل نطبيق البرنامج التثقيفي بلغت نسبة من كان لديهم معلومات غذائية صحيحة 0Y\%، ومن لديهم اتجاهات

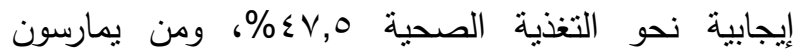
السلوك الغذائي الصحي 00\% فقط. بلغت تللك النسب بعد

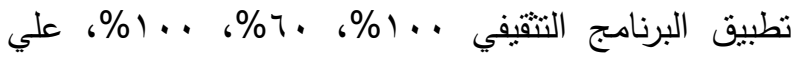
التوالي. أما برنامج التذخل الغذائي فقد أدي تطبيقه إلي حدوث تحسن في معظم المعايير التي تم قياسها للمرضي و التي شملت مؤشر كتلة الجسم، ووظائف الكبد والكلي، كما انخفضت نسبة من يعانون من الإكتئاب مع إرتفاع نسبة من ون

$$
\text { تحسنت حالتهم الصحية الوظيفية. }
$$

استخلصت الدراسة أن برامج التنقيف الغذائي و التدخل الغذائي هامة جدا لعلاج المدمنين ويجب أن نوجه للمرضي برائ بالتوازي مع العلاج الطبي والنفسي، وأن نطبق في المراحل الأولي للعلاج والتي تشمل إنسحاب المخدر، والتخلص من سموم الجسم والتأهيل لمساعدة الكبد وأجهزة الجسم الأخري علي أداء وظائفها بكفاءة.
يتسبب الإدمان في إحداث مشاكل نؤدي إلي سوء التغذية وأمراض نفسية. لذلك كان هدف هذه الدراسة هو التعرف لإندان علي تأثنير برامج تدخل تثقيفية وغذائية نركز علي مضادات هره

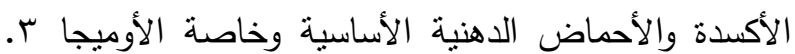
كان الهدف من البرامج هو تحسين المعلومات وتعديل الاتجاهات والسلوك الغذائي للمدمنين، وأيضاً تحسين حالتهم

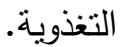

اشتملت عينة الدراسة علي عدد ·ع رجل مدمن في مرحلة التأهيل يعالجون في مستشفي المعمورة للأمراض النفسية بالإسكندرية. تم تجميع البيانات باستخدام استمارة استبيان بالمقابلة الشخصية، وعولجت البيانات إحصائياً. بلغت مدة البرنامج التثقيفي · 1 ساعات علي مدار ه أيام

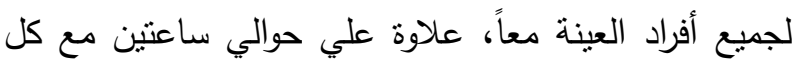

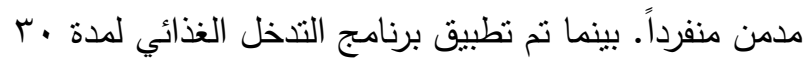

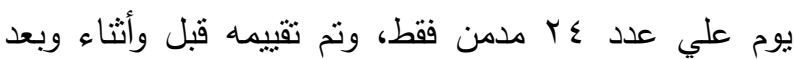
التطبيق.

أوضحت النتائج أن معظم المبحوثين كانوا من الثباب وأعمارهم أقل من · r سنة، وأن ثلثهم يعانون من مشاكل 